\title{
Examining the Differences between the Responses of the Students to a Digital Game and its Active Version According to their Mathematics Grades
}

\author{
Mehmet Inan ${ }^{1}$, Fatih Dervent ${ }^{2, *}$, Bülent Özden ${ }^{1} \&$ Bülent Arslantas ${ }^{3}$ \\ ${ }^{1}$ Ataturk Faculty of Education, Marmara University, Istanbul, Turkey \\ ${ }^{2}$ School of Physical Education and Sports, Marmara University, Istanbul, Turkey \\ ${ }^{3}$ Department of Physical Education and Sports, Istanbul Technical University, Istanbul, Turkey \\ *Correspondence: Marmara Universitesi, Beden Egitimi ve Spor Yuksekokulu, Anadoluhisari Kampusu, Beykoz, \\ Istanbul 34380, Turkey. Tel: 90-505-432-2626. E-mail: faith.dervent@marmara.edu.tr
}

Received: September 8, 2015

doi:10.5430/wje.v5n5p71
Accepted: September 23, $2015 \quad$ Online Published: October 7, 2015

URL: http://dx.doi.org/10.5430/wje.v5n5p71

\begin{abstract}
The purpose of this study was to examine students' responses to the digital and the active version of Angry Birds ${ }^{\mathrm{TM}}$ according to students' mathematics grades. The relational screening model was used to reveal the relationship between the students' responses and their math grades. The participants were 26 elementary and secondary school students enrolled in a state or a private school. Data was collected during the 2012-2013 academic year using a three-question semi-structured interview. First, the responses of the students were analyzed using the qualitative method of content analysis. The responses of the students were examined in two categories based on being either positive or negative. 39 codes were emerged from the responses to the digital games and active games. 27 of the codes were positive while 12 of them were negative. Students whose mathematics grades were 70 and above on a 100 point scale were grouped as high achievers. Those whose mathematics grades were below 70 were grouped as low achievers. Later, the chi-square test was employed to compare the categories with the students' mathematics grades. No significant difference was found between high and low achievers. After playing the digital version, low achievers gave more positive responses while high achievers gave more positive responses after playing the active version.
\end{abstract}

Keywords: digital games; active games; elementary school students; secondary school students; mathematics grades

\section{Introduction}

As a result of a stupendous progress in technology, digital technology has became a common aspect in people's lives, whether digital systems or devices. As a part of people's everyday lives, they can use digital technology anywhere and anytime; at homes, at working places or on their way to or back home. Digital technology is also used in educational settings. Teachers have started to use more digital technology to improve their teaching effectiveness and to encourage student learning. As a result, researchers take an interest in the educational effect of digital technology. Digital games also become a focus of educational studies.

Game based learning (GBL) comes up commonly in educational studies focusing on digital games. GBL is used as an instructional method (Bunch, Robinson, Shane, \& Antonenko, 2014; Prensky, 2003;), as a well-established approach (Liu, Rosenblum, Horton \& Kang, 2014, Naik \& Price, 2014), or as a model (Squire, 2005). It is asserted that GBL ensures more active participation by students (Burgos, Tattersall, \& Koper, 2007; Sung \& Hwang, 2013), which then improves student learning (Lai, Lin, Jong, \& Hsia, 2014; Yang \& Chang, 2013;). Park (2012) specifies that GBL motivates students, thus facilitating learning on complicated tasks. It contributes active learning (Mellecker, Witherspoon, \& Watterson, 2012) and problem solving skills (Chuang \& Chen, 2007).

Digital games are very popular as a free-time activity among children and occupy a great deal of time in their lives (Nippold, Duthie, \& Larson, 2005). Digital games, with their visual and audial properties, are considered more 
attractive than other types of games and traditional learning modes by children (Aydemir, 2011; Gee, 2003; Malta, 2010). They enable students to take the control of their own learning (De Grove, Bourgonjon, \& Van Looy, 2012). When combined with other types of games, digital games create a powerful learning environment (Oblinger, 2004; Prensky, 2001; Robertson \& Howells, 2008) that enhances learning effectiveness (Burgos et al., 2007; Saltzman, 1999). Digital games not only provide a strong motivation to learn (Bracey, 1992; Tuzun, Yilmaz-Soylu, Karakus, Inal, \& Kizilkaya, 2009) but also promote moral reasoning, which helps to shape positive behaviors (Koo \& Seider, 2010). Lainema and Saarinen (2010) indicate that digital games also foster cooperation. Other than the positive qualifications, digital games have some disadvantages such as increasing aggression (Griffiths, 1999; Prot, McDonald, Anderson, \& Gentile, 2012), undermining role identities (Hong, Cheng, Hwang, Lee, \& Chang, 2009), and causing inactivity. There have been efforts to combine digital games with active games in order to prevent negative causes of inactivity, which is considered the fourth leading cause of death worldwide (Kohl et al., 2012).

We observed that while playing digital games, students stayed inactive. From the point of view of physical educators, that inactivity is inherent in digital games was our standpoint before we started this study. As $97 \%$ of teens between ages 12 to 17 play digital games (Lenhart, 2008), we wanted to use this attractiveness (i.e., popularity) of digital games among children to make them active. We chose Angry Birds ${ }^{\mathrm{TM}}$ to use in this study. The reason this particular game was not only its popularity -as it became the number one paid application of all time within a few months of its release- but also the ease of adapting it to create an active version. However, we noticed some different aspects of the game such as planning, attention, focusing, and problem solving, which could also be considered as the components of mathematics. Then, we decided to examine the differences between the student responses to the digital and the active version of Angry Birds ${ }^{\mathrm{TM}}$ according to students' mathematics grades.

\section{Methods}

Examining the differences between the students' responses to the digital and the active version of Angry Birds ${ }^{\mathrm{TM}}$ according to students' mathematics grades was the purpose of this study. Relational screening model was used to reveal the differences between the students' responses and the grades (Karasar, 2012). After we selected the game Angry Birds ${ }^{\mathrm{TM}}$ for the study because of the reason mentioned above, we tried to design the active version of it on our university campus with second hand or recyclable materials in order to show that it could be produced in an easy and cheap way. The active version was installed at the students' school gyms. Students were invited to the gym by in groups of 4 or 5 students and given tablets. First, they played the digital version of Angry Birds ${ }^{\mathrm{TM}}$ for 30 minutes. Then, they played the active version of Angry Birds ${ }^{\mathrm{TM}}$ for another 30 minutes. After they were done playing, they were asked three questions: (1) what do you think about the digital game?, (2) what do you think about the active version?, and (3) how would do you describe your feelings? Interviews were conducted individually by the researchers at school gyms for their convenience. All the interviews were audiotaped.

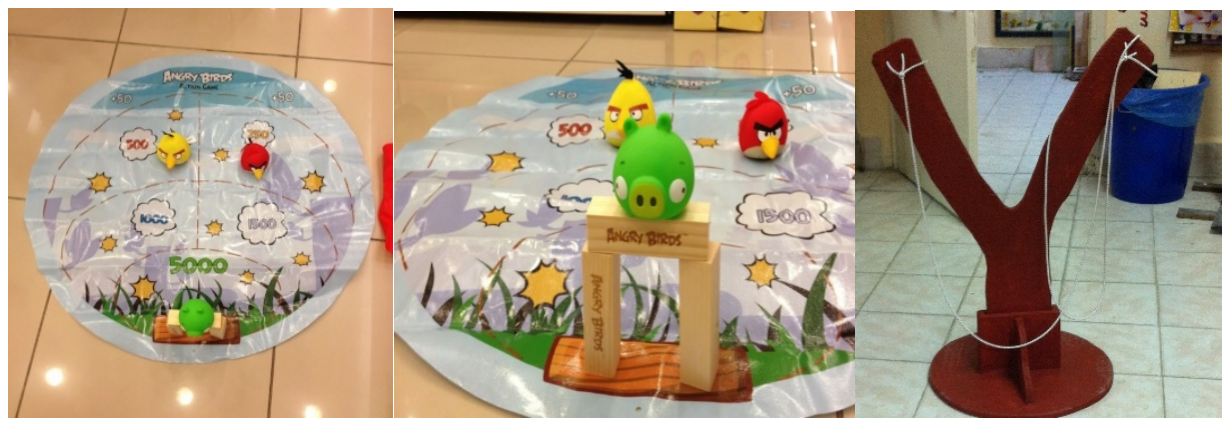

Figure 1. Materials Used for the Active Version

\subsection{Participants}

The participants were 26 elementary and secondary school students. 10 of them were enrolled in a private school and 16 were in a state school. 12 of the participants were females and 14 were males. The participants, parents, and school administrators were formally informed about the study purpose as well as the confidentiality and anonymity of the procedures. Parental consent forms and permissions from the schools were obtained. Preliminary demographic information such as age, gender, and school type as well as the participants' mathematics grades were obtained from the school administrations via the online database named "e-okul". All participants took part in the study voluntarily 
and were willing to discuss their thoughts and feelings. They were all familiar with Angry Birds ${ }^{\mathrm{TM}}$ and spent at least one hour a day playing digital games on tablets.

\subsection{Data Collection and Analysis}

First, the responses of the students were analyzed with the qualitative method of content analysis. 39 codes emerged from the responses to the digital game and the active game. The researchers were divided into two groups randomly (i.e., two researchers per a group). Two groups categorized the codes as either positive or negative, separately. The study was tested for reliability through the exchange of the two initial lists of codes. Two initial lists of codes created by two groups were compared. 27 codes were categorized as positive while 12 of them were negative. Since just one code was categorized differently, the reliability was found 0.97 . Reliability was computed by dividing the number of agreements by the number of agreements plus disagreements and then multiplying by 100 (Miles \& Hubermann, 1994). The reliability was found as $97 \%$ which met the $85 \%$ criterion suggested by Cooper, Heron and Heward (2007). Then, the students whose math grades were 70 or above on a 100-point scale were grouped as high achievers. Those with mathematics grades below 70 were grouped as low achievers. The criterion of achievement that is used by the Turkish Ministry of Education (MEB, 2007) was used to group the students. At the end, the chi-square test was employed to compare the categories with the students' mathematics grades.

Table 1. Codes for the Digital Game and the Active Version

\begin{tabular}{|c|c|c|c|c|c|}
\hline Positive & $\underset{f}{\text { Digital }}$ & $\underset{f}{\text { Active }}$ & Negative & $\underset{f}{\text { Digital }}$ & $\begin{array}{c}\text { Active } \\
\text { f }\end{array}$ \\
\hline Fun & 13 & 11 & Boring & 1 & 0 \\
\hline Love it & 1 & 0 & Aggressive & 7 & 1 \\
\hline Active & 1 & 1 & Monotonous & 1 & 1 \\
\hline Endeavour & 1 & 0 & It makes me sad & 2 & 0 \\
\hline Lets you blow off steam & 2 & 0 & Unhealthy (hurts my eyes) & 1 & 0 \\
\hline Happiness & 2 & 1 & I cannot do it & 0 & 1 \\
\hline Joy & 2 & 5 & Hard & 0 & 5 \\
\hline I never experienced before & 1 & 1 & Anger & 1 & 0 \\
\hline Made me laugh & 0 & 3 & Ambitious & 2 & 1 \\
\hline Exciting & 0 & 1 & Silly & 1 & 0 \\
\hline Being myself & 1 & 1 & I feel terrible & 0 & 1 \\
\hline Beautiful & 1 & 9 & Weird & 0 & 1 \\
\hline Realistic & 1 & 3 & & & \\
\hline I adjusted the way I want & 1 & 0 & & & \\
\hline I play whenever I am stressed & 0 & 1 & & & \\
\hline Attractive & 1 & 1 & & & \\
\hline Easy & 0 & 2 & & & \\
\hline Alive & 3 & 0 & & & \\
\hline I use my whole body & 1 & 0 & & & \\
\hline Adrenaline & 1 & 0 & & & \\
\hline Adventure & 0 & 1 & & & \\
\hline Enjoyable & 2 & 1 & & & \\
\hline Educative & 4 & 0 & & & \\
\hline Sharing & 3 & 3 & & & \\
\hline Adjusting & 1 & 0 & & & \\
\hline Moving & 1 & 1 & & & \\
\hline Controlling & 0 & 1 & & & \\
\hline Total & 44 & 47 & & 16 & 11 \\
\hline
\end{tabular}

\section{Results}

Table 1 shows the responses of the participants that played the digital and the active version of Angry Birds ${ }^{\mathrm{TM}}$. "Fun" was the most cited code both for the digital game and the active version. Participants referred to "fun" 13 times about the digital game and 11 times about the active version. The codes, "beautiful" ( $f=9)$ and "joy" ( $f=5)$, were cited more about the active version than the digital game. Participants also referred to the codes "alive" ( $\mathrm{f}=3$ ) and "educative" ( $\mathrm{f}=4)$ 
about the digital game while they referred to the codes "realistic" ( $\mathrm{f}=3)$, "easy" $(\mathrm{f}=2)$ about the active version. "Sharing" was cited 3 times both about the digital game and the active version. Participants referred to the positive codes 44 times about the digital game and 47 times about the active version.

It is noteworhty that the participants referred to code "aggressive" 7 times about the digital game when it is only cited once about the active version. The most cited negative code about the active version was "hard" ( $\mathrm{f}=5$ ). It was not referred to the digital game. Negative codes were cited 16 and 11 times about the digital game and the active version, respectively.

Table 2. Chi Square Analysis of the Participants' Responses to the Digital Game According to Mathematics Grades

\begin{tabular}{cccc} 
& & Positive & Negative \\
\hline Grades & High & $19(43.2)$ & $10(62.5)$ \\
& Low & $25(56.8)$ & $6(37.5)$ \\
& Total & $44(100)$ & $16(100)$ \\
\hline
\end{tabular}

Chi Square $=1.065 p>0.001$

To reveal any potential differences between the students' responses to the digital and the active version of Angry Birds $^{\mathrm{TM}}$ according to students' mathematics grades, the chi-square test was conducted. There was no significant difference between the responses of the participants about the digital game according to their mathematics grades $(\mathrm{p}>0.001)$. The percentage of the "negative" responses of the high achievers to the digital game was $62.5 \%$. Meanwhile the percentage of the "positive" responses of the low achievers to the digital game was $56.8 \%$.

Table 3. Chi Square Analysis of the Participants' Responses to the Active Version According to Mathematics Grades

\begin{tabular}{cccc}
\hline & & Positive & Negative \\
\hline Grades & High & $25(53.2)$ & $3(27.3)$ \\
& Low & $22(46.8)$ & $8(72.7)$ \\
& Total & $47(100)$ & $11(100)$ \\
\hline
\end{tabular}

Chi Square $=1.472 p>0.001$

No significant difference between the responses of the participants to the active version was found according to participants' mathematics grades ( $p>0.001$ ). Table 3 displays that the percentage of the "positive" responses of high achievers to the active version was $53.2 \%$. In contrast, the percentage of the "negative" responses of low achievers to the active version was $72.7 \%$, which is higher than the positive responses.

\section{Discussion}

Mathematics is one of the core courses starting from the very first year of educational life. The relationship between game playing and the understanding of mathematical concepts is not regarded as a brand new phenomenon. Mathematical skills blended with comprehension of geometrical figures, numbers, and arithmetic might be transferred to game playing. Lowrie and Jorgensen (2011) emphasize that activities that are enhanced with digital elements play an important role in learning mathematical knowledge. They assert that block games such as Lego stimulate mathematical thinking. Players might use their knowledge of geometrics, numbers, and arithmetic for reasoning and decision making while playing the digital version of Angry Birds ${ }^{\mathrm{TM}}$.

In the study, it is noteworthy that high achievers used more "positive" responses after they played the active version. Wallhead and Buckworth (2004) specify that the enjoyment level of activities increases physical activity level, which also promotes lifelong physical activity participation contributing to a healthy lifestyle (Allender, Cowburn, \& Foster, 2006; Mellecker, Witherspoon, \& Watterson, 2012). The most cited codes in this study are "fun", "joy" and "make me laugh". This seems to confirm the results of the above mentioned studies.

\section{Conclusion and İmplications}

In this study, the differences between the students' responses to the digital and the active version of Angry Birds ${ }^{\mathrm{TM}}$ according to students' mathematics grades were examined. Codes $(\mathrm{f}=39)$ emerged by content analysis categorized based on being either positive or negative. Positive codes were cited more about the active version $(\mathrm{f}=47)$ than the digital game $(\mathrm{f}=44)$. In contrast, negative codes were cited more about the digital game $(\mathrm{f}=16)$ than the active version 
$(\mathrm{f}=11)$. This appears to show that the participants developed a positive attitude towards the active version. Regarding the active version; low achievers referred to negative codes more than the positive ones while high achievers used more positive codes. Accordingly, it might be interpreted that low achievers tended to have a positive attitude towads the digital game. High achievers tended to be positive about the active version, which might be interpreted as one of the the most noteworthy results of the study.

\section{Limitations}

There are some limitations to this study including the limited sample size. Future researchers might prefer to use a longitudinal design. This might provide a deeper understanding of the students' responses. And, the transition of their responses might be examined. Also, observations of the researchers might be used to support the data. In addition, future studies might be conducted with active versions of different digital games and even involve grades in courses other than mathematics. Finally the relationship between the potential different games and different courses might be examined through GBL.

\section{References}

Allender, S., Cowburn, G., \& Foster, C. (2006). Understanding participation in sport and physical activity among children and adults a review of qualitative studies. Health Education and Research Theory and Practice, 21, 826-835. http://dx.doi.org/10.1093/her/cyl063

Aydemir, B. (2011). Dokunmatik ekran kullanımının öğrencilerin bilgisayar kulanımına ve eğitsel bilgisayar oyunlarına yönelik tutumlarına etkisinin araştırılması (Unpublished master thesis). Ege University, İzmir.

Bracey, G. W. (1992). The bright facture of integrated learning system. Educational Technology, 32, 60-62.

Bunch, J. C., Robinson, J. S., Edwards, M. C., \& Antonenko, P. D. (2014). How a serious digital game affected students' animal science and mathematical competence in agricultural education. Journal of Agricultural Education, 55(3), 57-71. http://dx.doi.org/10.5032/jae.2014.03057

Burgos, D., Tattersall, C., \& Koper, R. (2007). Re-purposing existing generic games and simulations for e-learning. Computers in Human Behavior, 23(6), 2656-2667. http://dx.doi.org/10.1016/j.chb.2006.08.002

Chuang, T., \& Chen, W. (2007). Effect of digital games on children's cognitive achievement. Journal of Multimedia, 2(5), 27-30. http://dx.doi.org/10.4304/jmm.2.5.27-30

Cooper, J. O., Heron, T. E., \& Heward, W. L. (2007). Applied behavior analysis. Upper Saddle River, NJ: Pearson.

De Grove, F., Bourgonjon, J., \& Van Looy, J. (2012). Digital games in the classroom? A contextual approach to teachers' adoption intention of digital games in formal education. Computers in Human Behavior, 28, 2023-2033. http://dx.doi.org/10.1016/j.chb.2012.05.021

Gee, J. P. (2003). What video games have to teach us about learning and literacy. New York: Palgrave MacMillian.

Griffiths, M. (1999). Violent video games and aggression: A review of the literature. Aggression and Violent Behavior, 4(2), 203-212. http://dx.doi.org/10.1016/S1359-1789(97)00055-4

Hong, J. C., Cheng, C. L., Hwang, M. Y., Lee, C. K., \& Chang, H. Y. (2009). Assessing the educational values of digital games. Journal of Computer Assisted Learning, 25, 423-437. http://dx.doi.org/10.1111/j.1365-2729.2009.00319.x

Karasar, N. (2012). Bilimsel araştırma yöntemi. Ankara: Nobel Akademik Yayıncılık.

Kohl, H., Craig, C., Lambert, E., Inove, S., Alkandari, J., Leetongin, G., \& Kahlmeier, S. (2012). The pandemic of physical inactivity; global action for public health. The Lanecet, 380, 294-305. http://dx.doi.org/10.1016/S0140-6736(12)60898-8

Koo, G., \& Seider, S. (2010). Ethics and game design: Teaching values through play. In Karen, S., \& David G. (Eds.), Video games for pro-social learning (16-33). Hershey, NY: Information Science Reference.

Lai, C., Lin, Y., Jong, B., \& Hsia, Y. (2014). Adding social elements to game-based learning. IJET, 9(3), 12-15. http://dx.doi.org/10.3991/ijet.v9i3.3294

Lainema, T., \& Saarinen, E. (2010). Design and implementation of educational games: Theoretical and practical perspectives. In Pavel Z., \& Diane W. (Eds), Explaining the educational power of games (17-31). Hershey, NY: Information Science Reference. 
Liu, M., Rosenblum, J. A., Horton, L., \& Kang, J. (2014). Designing science learning with game-based approaches. Computers in the schools: Interdisciplinary Journal of Practice, Theory, and Applied Research, 31(1-2), 84-102. http://dx.doi.org/10.1080/07380569.2014.879776

Lowrie, T., \& Jorgensen, R. (2011). Gender differences in students' mathematics game playing. Computers \& Education, 57, 2244-2248. http://dx.doi.org/10.1016/j.compedu.2011.06.010

Malta, S. (2010). Illköğretimde kullanılan ĕgitsel bilgisayar oyunlarının öğrencilerin akademik başarılarına etkisi (Unpublished master thesis). Sakarya University, Sakarya.

MEB (2007). İlköğretim $\quad$ kurumları $\quad$ yönetmeliği. $\quad$ Retrieved from http://www.resmigazete.gov.tr/eskiler/2007/08/20070820-1.htm

Mellecker, R. R., Witherspoon, L., \& Watterson, T. (2013). Active learning: Educational experiences enhanced through technology-driven active game play. The Journal of Educational Research, 106, 352-359. http://dx.doi.org/10.1080/00220671.2012.736429

Naik, N., \& Price, D. (2014). Take it easy, it is games not mathematics. In $2^{\text {nd }}$ HEA Future Directions for Higher Education in Wales Conference, Wales.

Nippold, M., Duthie, J., \& Larson, J. (2005). Literacy as a leisure activity: Free-time preferences of older children and young adolescents. Language, Speech and Hearing Services in Schools, 36(2), 93-102. http://dx.doi.org/10.1044/0161-1461(2005/009)

Oblinger, D. (2004). The next generation of educational engagement. Journal of Interactive Media in Education, 8, 1-18. http://dx.doi.org/10.5334/2004-8-oblinger

Park, H. (2012). Relationship between motivation and student's activity on educational game. International Journal of Grid and Distributed Computing, 5(1), 101-113.

Prensky, M. (2001). Types of learning and possible game styles, digital game-based learning. USA: McGraw-Hill.

Prensky, M. (2003). Digital game-based learning. Computers in Entertainment (CIE), 1(1), 21-21. http://dx.doi.org/10.1145/950566.950596

Prot, S., McDonald, K. A., Anderson, C., \& Gentile, D. A. (2012). Video games: Good, bad, or other. Pediatric Clinics of North America, 59(3), 647-658. http://dx.doi.org/10.1016/j.pcl.2012.03.016

Robertson, J., \& Howells, C. (2008). Computer game design: Opportunities for successful learning. Computers \& Education, 50, 559-578. http://dx.doi.org/10.1016/j.compedu.2007.09.020

Saltzman M. (1999). Game design: Secrets of the sages. Indianapolis: Brady.

Squire, K., Giovanetto, L., Devane, B., \& Durga, S. (2005). From users to designers: Building a self-organizing game-based learning environment. TechTrends: Linking Research \& Practice to Improve Learning, 49(5), 34-43. http://dx.doi.org/10.1007/BF02763688

Sung, H., \& Hwang, G. (2013). A collaborative game-based learning approach to improving students' learning performance in science courses. Computers \& Education, 63, 43-51. http://dx.doi.org/10.1016/j.compedu.2012.11.019

Tuzun, H., Yilmaz-Soylu, M., Karakus, T., Inal, Y., \& Kizilkaya, G. (2009). The effects of computer games on primary school students' achievement and motivation in geography learning. Computers \& Education, 52, 68-77. http://dx.doi.org/10.1016/j.compedu.2008.06.008

Wallhead, T. L. \& Buckworth, J. (2004). The role of physical education in the promotion of youth activity. Quest, 56, 285-301. http://dx.doi.org/10.1080/00336297.2004.10491827

Yang, Y.T. C., \& Chang, C. (2013). Empowering students through digital game authorship: Enhancing concentration, critical thinking, and academic achievement. Computers \& Education, 68, 334-344. http://dx.doi.org/10.1016/j.compedu.2013.05.023 